\title{
Experimental Studies of Decapod and Fish Predation on Seagrass Macrobenthos*
}

\author{
by Walter G. Nelson** \\ Harbor Branch Institution, Inc., RR 1, Box 196-A, Fort Pierce, Florida 33450, USA
}

\begin{abstract}
The effects of 1 fish and 3 decapod crustaceans were examined in laboratory and field predator enclosure experiments in the Indian River Lagoon, Florida, USA. Results of laboratory and field experiments were similar in most cases. The fish Lagodon rhomboides and the crab Callinectes sapidus had relatively little effect on macrofaunal abundances. In contrast, the shrimps Palaemonetes intermedius and particularly Penaeus duorarum exerted marked negative effects on the density of almost all macrobenthic taxa present. The role of shrimps and other decapods in regulating densities of seagrass macrobenthos may be much greater than previously thought. The decapod crustaceans appear to be important keys to the understanding of trophic complexity in seagrass ecosystems.
\end{abstract}

\section{INTRODUCTION}

Field experimental studies of seagrass-associated macrobenthos of the Indian River, Florida, USA (Young et al., 1976) indicated that predation by fishes and decapod crustaceans plays an important role in regulation of species densities. Young et al. (1976) suggested that decapod crustaceans constitute unexpectedly important predators on the other macrofauna in this system. Experiments by Virnstein (1978, and pers. comm.) in the Indian River have confirmed that decapod predators are potentially important regulators of macrobenthic species densities.

Although these studies have identified important groups of predators, the identity of particularly significant predator species has remained uncertain. For the fishes, gut content studies indicate species of potential interest (Kikuchi, 1966; Carr and Adams, 1973; Littlejohn et al,, 1974; Adams, 1976). Among the fishes common along the southern coast of the United States, the highly abundant epibenthic predator Lagodon rhomboides (pinfish) is considered of major importance in regulating some components of the seagrass macrobenthos (Thayer et al., 1975; Nelson, 1979b; Stoner, 1979). Much less is known about the

\footnotetext{
- Contribution No. 217 of the Harbor Branch Foundation

- Present address: United States Environmental Protection Agency, Marine Science Center, Newport, Oregon 97365, USA
}

decapods. Callinectes sapidus (blue crab) has been shown to be an important predator on the infaunal macrobenthos of sand bottoms in Chesapeake Bay (Virnstein 1977, 1978). However, Orth (1977) and Virnstein (1977) suggested that in seagrass beds $C$. sapidus may be an effective predator only on the epifaunal and not infaunal benthos due to difficulties encountered in penetrating the seagrass rhizome mat. In an attempt to examine further their predation regulation hypothesis, Young and Young (1978) carried out additional manipulative field experiments which involved the placement of $L$. rhomboides and $C$. sapidus in large-mesh $(12 \mathrm{~mm})$ cage enclosures. These experiments, however, failed to show any significant impact by either species on densities of the macrobenthos.

In addition to Callinectes sapidus, at least 37 other decapod species occur in seagrass beds in the Indian River (Gore et al., 1981). Indeed, C. sapidus comprises only $0.5 \%$ (relative numerical abundance) of the decapod crustaceans of this habitat (Gore et al., 1981). It is therefore important to consider the role of some of these additional decapod species. Both Palaemonetes intermedius and Penaeus duorarum $18 \%$ and $6.5 \%$ of total abundance in the Indian River, respectively; Gore et al., 1981) are opportunistic omnivores, often ingesting significant quantities of animal material (Odum and Heald, 1972). However, shrimps of these genera have been little considered as potentially significant predators on macrobenthos.

It is clear that, despite evidence for the importance of 
predation in regulating species densities of seagrass macrobenthos in the Indian River, considerable uncertainties remain concerning the relative roles of the different types of predators present. The present study had the following aims: (1) to determine the efficiency of Lagodon rhomboides and Callinectes sapidus as predators on the macrobenthos; (2) to examine the role played by the numerically abundant shrimp Palaemonetes intermedius and Penaeus duorarum in regulating macrobenthic species densities; and (3) to assess which components of the seagrass macrobenthos (if any) are most susceptible to predation by each of the above species. To accomplish these goals, the effects of each predator species on the macrobenthos associated with the seagrass Halodule wrightii were evaluated through laboratory aquaria experiments with intact cores and field experiments with predator inclusion structures.

\section{MATERIALS AND METHODS}

All field experiments and collections of experimental animals for both field and laboratory experiments were carried out at the Link Port study site of Young et al. (1976) and Virnstein (1978) (27\%32.1' $\left.\mathrm{N}, 80^{\circ} 10.3^{\prime} \mathrm{W}\right)$, located in the Indian River, Florida, USA. The physical aspects of this location have been described in detail (Young et al., 1976; Young and Young, 1977, 1978).

Laboratory experiments were carried out in 19-1 aquaria located in a covered, screened outdoor enclosure. Each aquarium was divided in half with $1 \mathrm{~mm}$ mesh fiberglass window-screen. During each experiment, an individual aquarium contained both a control and an experimental side. Designation of control and experimental cores was at random. Randomly located intact cores $(15 \times 15 \times 15 \mathrm{~cm})$ of Halodule wrightii and sediment were collected at the Link Port site using the coring device described by Young et al. (1976). The cores were placed in buckets of seawater, transported and rapidly transferred (usually within 30-60 min of collecting the first core) into the experimental aquaria. All material remaining in a bucket following transfer of a core was sieved on $1 \mathrm{~mm}$ mesh and material retained was added to the core to which it belonged. An airstone was placed in each half of every aquarium. The aquaria were allowed to settle for $24 \mathrm{~h}$ before an experiment was begun. Each individual experiment involved 4 aquaria. Densities of predators utilized in each experiment were: (1) Lagodon rhomboides experiment - 1 fish (10-11 cm in total length) per experimental core; (2) Penaeus duorarum experiment - 4 shrimp (6.5-8.5 cm in total length) per experimental core; (3) Palaemonetes intermedius experiment -20 shrimp (2-3 cm in total length) per experimental core; (4) Callinectes sapidus experiment - $1 \mathrm{crab}$ (9.5-14.0 $\mathrm{cm}$ in carapace width) per experimental core. Dates for the beginning of these experiments were: (1) November 30, 1978; (2) May 4, 1979; (3) May 29, 1979; (4) July 21, 1979. Field experiments in all cases started no more than $7 \mathrm{~d}$ after initiation of the laboratory experiment with the same species.

All laboratory experiments ran for $21 \mathrm{~d}$, after which all material in each aquarium compartment was removed and washed on a $1 \mathrm{~mm}$ mesh sieve. Samples were placed in a solution of $0.15 \%$ propylene phenoxytol in sea water for 20-30 min, transferred to a $5-10 \%$ solution of formalin and rose bengal in sea water for $48 \mathrm{~h}$, and transferred to $70 \%$ ethyl alcohol.

Field experiments were done in cages $50 \times 50 \times$ $50 \mathrm{~cm}$ constructed of $1 \mathrm{~mm}$ mesh window-screen stapled to a wood frame with removable screen tops to allow access to the interior of the cage. Cages were placed in a shallow, subtidal bed of Halodule wrightii in 2 rows of 4 cages, cach parallel to the shoreline with treatments randomly assigned to cages. Maximal water depth was approximately $1 \mathrm{~m}$ at high tide. The bottom edges of the cages were approximately $10 \mathrm{~cm}$ in the sediment. No holes or evidence of burrowing under cages were found. Field experiments consisted of 4 experimental predator inclusion cages, 4 cages as a control for cage effects, and 4 control samples taken from the immediately surrounding seagrass bed. Densities of predators utilized in each experiment were: (1) 4 Lagodon rhomboides $(10-11 \mathrm{~cm}$ in total length) per inclusion cage; (2) 40 Penaeus duorarum (4-9 cm in total length) per inclusion cage: (3) 200 Palaemonetes intermedius (1-3 cm in length) per inclusion cage; (4) 1 Callinectes sapidus $(12-13 \mathrm{~cm}$ in carapace width) per inclusion cage. Predator densities were higher than average values but approximate naturally occurring densities in localized patches.

All field experiments ran $21 \mathrm{~d}$ except the experiment with Callinectes sapidus which ran $22 \mathrm{~d}$. The length was selected to minimize possible cage effects. At the termination of an experiment, 1 core was taken from the center of each cage and 4 cores were taken from the undisturbed grassbed. These samples were processed as described for the aquaria samples. Each cage was extensively sampled with a $6 \mathrm{~mm}$ mesh dipnet to capture the larger mobile fauna missed by the coring device. Except for the experiment with Lagodon rhomboides, 4 control samples of the larger mobile fauna were obtained from the surrounding seagrass bed. To take these samples, a cage structure was randomly placed in the bed, driven into the sediment, and its interior was sampled in an identical manner to that for the regular cage structures. Abundance values obtained from the dipnet samples will be distinguished from values obtained from the cores by terming them 'mobile fauna' abundances. 
Data from the field experiments were analysed with one-way analysis of variance to test 2 a priori hypotheses concerning differences in the sample means. Null hypothesis 1 was that the mean for the control samples equalled that of the inclusion cages. Null hypothesis 2 was that the mean of the control samples equalled that of the control cages. Rejection of Hypothesis 1 and acceptance of Hypothesis 2 would indicate the pre- sence of an effect due to the enclosed animals and not the cage itself. Following these analyses, where significant $F$ values were found, a posteriori comparisons were made to compare the means of the predator inclusion and control cages using the Student-Neuman-Keuls test. The laboratory experiment data were analysed with t-tests.

In several cases, heterogeneous variances were

Table 1 List of macrobenthic species of higher taxa collected in Indian River, Florida. 1: Species found in both core and dipnet samples; 2: species found only in dipnet samples

Annelida

Polychaeta

Oligochaeta

Arthropoda (Crustacea)

Amphipoda

Ampelisca abdita

Ampithoe longimana

Corophium ellisi

Corphium lacustre

Cymadusa compta

Gammarus mucronatus

Gitanopsis tortugae

Grandidierella bonnieroides

Melita elongata

Decapoda

Alpheus heterochelis

Ambidexter symmetricus

Callinectes sapidus

Hippolyte pleurocantha

Libinia dubia

Neopanope packardii

Neopanope sayi

Pagurus c.f. bonairensis

Palaemonetes intermedius

Penaeus duorarum

Isopoda

Cymodoce faxoni

Erichsonella attenuata

Tanidacea ${ }^{*}$

Hargeria rapax

Echinodermata

Amphioplus thromboides

Mollusca

Pelecypoda

Amygdalum papyrium

Anomalocardia auberiana

Brachiodontes exustus

Chione cancellata

Lyonsia hyalina floridana

Mercenaria mercenaria

Mulinia lateralis

Sphenia antillensis

Tellina tampaensis
Mollusa

Gastropoda *

Aceteocina candei

Astyris lunata

Bittium varium

Cerithiopsis greenii

Costoanachis avara

Crepidula convexa

Crepidula plana

Haminoea antillarum

Melongea corona

Modulus modulus

Nassarius vibex

Neritina virginea

Pyrocythara plicosa

Sayelle crosseana

Turbonilla sp.

Nemertinea

Sipuncula ${ }^{*}$

Phascolion cryptus

Vertebrata

Pisces

Bairdiella chrysura 2

Bathygobius soparator 2

Floridicthys carpio 2

Gobiosoma robustum 2

Lagodon rhomboides 2

Lucania parva 2

Microgobius gulosus 2

Poecilia latipinna 2

Strongylura sp. 2

Syngnathus scovelli

- Groupings subjected to statistical analysis 
found between treatments (F-max test). In such cases, the log transformation was applied to the data. Where this transformation failed to correct the heterogeneity, non-parametric methods were used. In a few instances where data from a single replicate were radically different from other replicates, these values were tested to determine whether they were statistical 'outliers' following the suggestions of Grubbs (1969). If the data were significantly different from the other replicates, such values were removed from the above analyses. All statistical analyses follow Sokal and Rohlf (1969).

Identification of animals collected was to species in most cases. The polychaetes, oligochaetes, and nemerteans were counted but not identified in this study. A list of species found and the taxonomic groupings utilized for statistical analysis are given in Table 1. Further information on faunal composition, density, and distribution can be found in Young et al. (1976) and Young and Young $(1977,1978)$.

\section{RESULTS}

\section{Experiments with Lagodon rhomboides}

The results of the laboratory experiments with Lagodon rhomboides are presented in Table 2. Of the 10 animal groupings analysed, only the total number of individuals was significantly lower in the fish addition treatment. However, values for most of the other categories were 30-50\% lower in the fish addition treatment.
In the analysis of the field experiment with Lagodon rhomboides, it was found that one replicate of the control cage treatment contained 113 Palaemonetes intermedius as compared to 10,10, and 4 in the other replicates. This replicate was excluded from further data analyses. The ANOVA results (Table 2) show no significant effects on the macrobenthos due to the presence of $L$. rhomboides. In fact abundances, especially of polychaetes, were higher than controls inside the cages with $L$. rhomboides. However, the abundances of decapods and isopods were significantly greater in the cage control than in the control samples. Abundances of the total 'mobile fauna' and of the 'mobile decapod' component were significantly greater in the control cages than in the cages with $L$. rhomboides (Table 2). There were no significant differences in any groups of macrobenthos between control cages and cages with L. rhomboides (a posteriori S-N$\mathrm{K}$ tests).

\section{Experiments with Penaeus duorarum}

Specimens of Penaeus duorarum in the tank experiment had significant effects on most groups of the seagrass macrobenthos (Table 3 ). There was a $90 \%$ reduction in total macrobenthos abundance over the 3 week duration of the experiment in the aquaria with $P$. duorarum. Significantly lower values for the polychaetes, decapods, amphipods, isopods, tanaids, nemerteans, and sipunculids were observed (Table 3 ). Tanaids, nemerteans, and sipunculids were totally

Table 2. Mean abundances (ind. $225 \mathrm{~cm}^{-2}$; with 1 standard deviation) for 10 and 15 groupings of organisms from tank and field experiments with Lagdon rhomboides, respectively. $N=4$, except $n=3$ for the experiment control cages treatment. No control samples of 'mobjle fauna' were taken in the field experiment

\begin{tabular}{|c|c|c|c|c|c|}
\hline \multirow[t]{2}{*}{ Organisms } & \multicolumn{2}{|c|}{ Tank experiment } & \multicolumn{3}{|c|}{ Field experiment } \\
\hline & Control & $\begin{array}{l}\text { Predator } \\
\text { inclusion }\end{array}$ & $\begin{array}{l}\text { Predator } \\
\text { inclusion }\end{array}$ & Control & Control cages \\
\hline Total & $106.5(24.9)^{\circ}$ & $62.8(23.0)$ & $374.8(141.7)$ & $292.8(56.9)$ & $425.6(246.4)$ \\
\hline Polychaeta & $73.5(30.2)$ & $44.5(19.6)$ & $338.5(155.2)$ & $268.3(48.4)$ & $342.6(215.2)$ \\
\hline Amphipoda & $8.8(11.1)$ & $4.0(4.3)$ & $15.3(20.0)$ & $6.8(7.3)$ & $37.7(41.2)$ \\
\hline Decapoda & $1.3(0.5)$ & $0.5(1.0)$ & $4.8(3.9)$ & $3.3(2.1)^{\circ}$ & $15.0(11.0)$ \\
\hline Isopoda & $1.8(1.7)$ & $0.8(1.5)$ & $2.5(1.3)$ & $1.3(1.0)^{\circ}$ & $7.0(5.2)$ \\
\hline Tanaidacea & 0 & 0 & 0 & 0 & 0 \\
\hline Pelecypoda & $1.3(1.3)$ & $0.8(0.5)$ & $3.8(2.2)$ & $1.3(1.0)$ & $3.7(1.5)$ \\
\hline Gestropoda & $17.3(9.3)$ & $11.0(4.9)$ & $8.3(4.8)$ & $8.0(4.1)$ & $14.6(4.5)$ \\
\hline Nemertinea & 0 & 0 & 0 & $0.5(1.0)$ & 0 \\
\hline Sipuncula & 0 & $0.3(0.5)$ & $1.3(1.9)$ & $0.3(0.5)$ & $0.7(1.2)$ \\
\hline Total 'mobile Iauna' & - & - & $1.8(1.0)$ & - & $10.3(4.0)$ \\
\hline 'Mobile fish' & - & - & $0.8(0.5)$ & - & $1.0(1.0)$ \\
\hline 'Mobile decapods' & - & - & $1.0(0.8)$ & - & $8.0(3.5)$ \\
\hline Mobile Palaemonetes & - & - & 0 & - & $0.3(0.6)$ \\
\hline 'Mobile' Penaeus & - & -- & $0.5(0.6)$ & - & $3.3(4.0)$ \\
\hline
\end{tabular}


Table 3. Mean abundances (ind. $225 \mathrm{~cm}^{-2}$; with 1 standard deviation) for 10 and 15 groupings of organisms from tank and field experiments with Penaeus duorarum, respectively. $\mathrm{N}=4$, for all treatments

\begin{tabular}{|c|c|c|c|c|c|}
\hline \multirow[t]{2}{*}{ Organisms } & \multicolumn{2}{|c|}{ Tank experiment } & \multicolumn{3}{|c|}{ Field experiment } \\
\hline & Control & $\begin{array}{l}\text { Predator } \\
\text { inclusion }\end{array}$ & $\begin{array}{l}\text { Predator } \\
\text { inclusion }\end{array}$ & Control & Control cages \\
\hline Total & $247.8(73.7)^{\circ}$ & $22.8(11.3)$ & $82.3(45.9)^{\circ}$ & $381.0(84.4)$ & $320.3(130.1)$ \\
\hline Polychaeta & $145.3(54.1)^{\circ}$ & $14.5(7.9)$ & $68.5(41.3)^{\circ}$ & $277.3(66.7)$ & $203.8(89.9)$ \\
\hline Amphipoda & $35.3(26.3)^{\circ}$ & $2.5(2.9)$ & $2.0(1.8)$ & $4.8(3.4)^{\circ}$ & $36.8(27.0)$ \\
\hline Decapoda & $1.8(1.3)^{\circ}$ & $0.3(0.5)$ & $0.8(0.5)^{\circ}$ & $2.3(0.5)$ & $2.5(1.3)$ \\
\hline Isopoda & $8.5(5.3)^{\circ}$ & $0.3(0.5)$ & 0 & $1.3(1.4)^{\bullet}$ & $27.3(30.2)$ \\
\hline Tanaidacea & $35.0(20.7)^{\circ}$ & 0 & $0.5(1.0)^{\circ}$ & $70.5(17.1)^{\circ}$ & $22.0(16.8)$ \\
\hline Pelecypoda & $0.8(1.0)$ & $0.3(0.5)$ & $0.8(1.0)$ & $2.8(2.5)$ & $1.5(0.6)$ \\
\hline Gastropoda & $6.0\{3.3\}$ & $5.3(3.6)$ & $2.8(2.9)$ & $9.3(3.2)$ & $13.8(13.9)$ \\
\hline Nemertinea & $5.0(3.3)^{\circ}$ & 0 & $2.8(1.5)^{\circ}$ & $1.0(0.0)^{\circ}$ & $4.5(1.0)$ \\
\hline Sipuncula & $4.3(3.4)^{\circ}$ & 0 & $0.5(1.0)$ & $0.8(0.5)$ & $2.8(2.8)$ \\
\hline Total 'mobile fauna' & - & - & $5.8(3.8)$ & $7.0(3.9)$ & $14.5(9.8)$ \\
\hline 'Mobile fish' & - & - & $0.5(0.6)$ & $0.8(1.0)$ & $2.5(1.7)$ \\
\hline 'Mobile decapods' & - & - & $5.3(3.5)$ & $6.3(3.3)$ & $12.0(8.2)$ \\
\hline 'Mobile' Palaemonetes & - & - & $2.5(2.6)$ & $1.3(1.9)$ & $7.8(5.7)$ \\
\hline 'Mobile' Penaeus & - & - & - & $4.3(2.9)$ & $3.0(2.7)$ \\
\hline
\end{tabular}

absent from the aquaria with $P$. duorarum, and isopods and decapods nearly so. Only the molluscs were unaffected.

Results from the field experiment also indicate a significant impact of Penaeus duorarum on certain faunal elements (Table 3). Total macrobenthos abundance was reduced by $78 \%$ in the cages with $P$. duorarum as compared with controls. Significantly lower densities in the cages with $P$. duorarum also were found for the polychaetes, decapods, and tanaids.
In contrast to the tank experiment, nemerteans were significantly more abundant inside the cages with $P$. duorarum than in controls. Significantly greater numbers of amphipods, isopods, and nemerteans were found inside control cages as compared with controls, indicating a significant cage effect for these groups. Significantly lower numbers of tanaids were found in control cages than in controls (Table 3). A posteriori analysis of all ANOVA comparisons with significant $F$ values showed that in all cases (except for the tanaids)

Table 4. Mean abundances (ind. $225 \mathrm{~cm}^{-2}$; with 1 standard deviation) for 10 and 15 groupings of organisms from tank and field experiments with Palaemonetes intermedius, respectively. $\mathrm{N}=4$, except $\mathrm{n}=3$ for tank experiment control. A: data transformed

(log) for statistical comparison, untransformed data given here; B: data analysed with non-parametric STP test

\begin{tabular}{|c|c|c|c|c|c|}
\hline \multirow[t]{2}{*}{ Organisms } & \multicolumn{2}{|c|}{ Tank experıment } & \multicolumn{3}{|c|}{ Field experiment } \\
\hline & Control & $\begin{array}{l}\text { Predator } \\
\text { inclusion }\end{array}$ & $\begin{array}{l}\text { Predator } \\
\text { inclusion }\end{array}$ & Control & Control cages \\
\hline Total & $197.7(17.4)^{\circ}$ & $119.0(45.5)$ & $74.3(51.1)^{\circ}$ & $169.3(51.3)$ & $91.3(51.71)$ \\
\hline Polychaeta & $144.3(15.3)$ & $106.5(49.7)$ & $61.8(42.7)^{\circ}$ & $143.0(47.8)$ & $47.8(29.9)$ \\
\hline Amphipoda & $19.2(21.2)^{\circ} \mathrm{A}$ & $2.3(0.5)$ & $2.8\{2.8\}$ & $2.0(1.2)$ & $6.8(5.1)$ \\
\hline Decapoda & $1.3(0.6)^{\circ}$ & 0 & $0.5(0.6) \cdot B$ & $3.0(1.2)$ & $6.0(6.7)$ \\
\hline Isopoda & $2.0(2.7)$ & $0.5(0.6)$ & $3.5(3.1)$ & $2.5(1.0)$ & $3.5(3.1)$ \\
\hline Tanaidacea & $19.0(20.1)$ & $4.5(3.4)$ & $1.3(1.5)^{\circ} \mathrm{A}$ & $9.3(4.9)$ & $13.8(16.2)$ \\
\hline Pelecypoda & $1.0(0.0)$ & $1.5(1.3)$ & $0.3(0.5)$ & $1.8(1.7)$ & $0.5(1.0)$ \\
\hline Gastropoda & $1.0(1.0)$ & $1.5(1.0)$ & $1.8(1.5)^{\circ}$ & $5.5(3.1)$ & $9.0(1.6)$ \\
\hline Nemertinea & $1.7(1.5)$ & $1.5(1.7)$ & $2.3(2.1)$ & $1.0(0.8)$ & $3.0(2.2)$ \\
\hline Sipuncula & $4.7(3.1)^{\circ}$ & $0.3(0.5)$ & 0 & $1.0(0.8)$ & $1.0(1.4)$ \\
\hline Total 'mobile fauna' & - & - & $4.5(0.6)^{\circ} \mathrm{A}$ & $8.5(3.8)^{\circ} \mathrm{A}$ & $29.5(12.3)$ \\
\hline 'Mobile fish' & - & - & $2.3(0.5)^{\bullet}$ & $0.3(0.5)^{\circ}$ & $2.3(1.9)$ \\
\hline 'Mobile decapods' & - & - & $2.0(0.8)^{\circ} \mathrm{A}$ & $8.3(4.0)^{\circ} \mathrm{A}$ & $27.3(10.0)$ \\
\hline 'Mobile' Palaemonetes & -- & - & - & $7.5(3.4)$ & $21.5(10.1)$ \\
\hline 'Mobile' Penaeus & -- & - & $1.0(0.8)$ & $0.8(1.0)$ & $4.5(2.9)$ \\
\hline
\end{tabular}


abundance values of the control cages were significantly greater than for the cages with $P$. duorarum.

\section{Experiments with Palaemonetes intermedius}

In the analysis of laboratory experiment results with Palaemonetes intermedius, 1 control replicate was excluded because its total abundance value was significantly different from the other 3 values. Categories which showed significant reductions in abundance in the aquaria with $P$. intermedius were total macrobenthos, amphipods, decapods, and sipunculids (Table 4). Isopods and tanaids showed a $75 \%$ reduction in abundance but variances were high and these differences were not statistically significant. Molluscs were not affected by the presence of $P$. intermedius.

In the field experiment, inclusion of Palaemonetes intermedius resulted in significant decreases of abundance of total macrobenthos, polychaetes, decapods, and tanaids (Table 4 ). A significant decrease was also found for the gastropods. Among comparisons based on the core samples, only the polychaetes showed any significant difference between the controls and control cages, being more abundant in the controls. Among the 'mobile fauna' comparisons, there were significantly lower abundances of total 'mobile fauna' and 'mobile decapods', but a higher abundance of 'mobile fish' in the inclusion cages as compared with the controls. The control cages had significantly greater abundances than for the controls of 'mobile fauna', 'mobile fish', 'mobile decapods', and 'mobile penaids'.
A posteriori comparisons between results from the control cages and the inclusion cages indicated the presence of higher abundances of gastropods as well as total 'mobile fauna', 'mobile decapods', and 'mobile penaids' in the control cages. Since the control cage densities of these groups were also higher in all cases than for controls, a significant reduction of predator intensity due to the presence of the cage on these faunal elements is indicated.

\section{Experiments with Callinectes sapidus}

Total macrofaunal abundance was significantly lower in experimental aquaria with Callinectes sapidus present than in the control aquaria, mean densities having been reduced by $70 \%$ (Table 5). Tanaid and gastropod abundances were significantly reduced. Bivalves showed no differences between treatment and control, perhaps because of their already low density in the control tanks (Table 5). Both polychaetes and amphipods showed large reductions of mean abundance in the presence of $C$. sapidus $158 \%$ and $75 \%$, respectively) but neither difference was statistically significant due to large variability.

Results of the field experiment with Callinectes sapidus (Table 5) differed markedly in some respects from the tank experiment. Total macrobenthos abundance was significantly greater in the cages with $C$. sapidus than in either the control cages or controls (Table 5, results from ANOVA and S-N-K). This difference was due primarily to large increases in

Table 5. Mean abundances (ind. $225 \mathrm{~cm}^{-2}$; with 1 standard deviation) for 10 and 15 groupings of organisms from tank and field experiments with Callinectes sapidus, respectively. $\mathrm{N}=4$, except $\mathrm{n}=3$ for field experiment control cages treatment. A: data transformed (log) for statistical comparison, untransformed data given here

\begin{tabular}{|c|c|c|c|c|c|}
\hline \multirow[t]{2}{*}{ Organisms } & \multicolumn{2}{|c|}{ Tank experiment } & \multicolumn{3}{|c|}{ Field experiment } \\
\hline & Control & $\begin{array}{l}\text { Predator } \\
\text { inclusion }\end{array}$ & $\begin{array}{l}\text { Predator } \\
\text { inclusion }\end{array}$ & Control & Control cages \\
\hline Total & $160.3(56.7)^{\circ}$ & $48.0(12.6)$ & $129.3(37.6)^{\circ}$ & $77.8(23.3)$ & $58.7(16.2)$ \\
\hline Polychaeta & $83.8(61.6)$ & $35.0(18.0)$ & $51.8(22.5)$ & $38.3(16.6)$ & $25.0(11.3)$ \\
\hline Amphipoda & $20.0(19.0)$ & $5.0(6.4)$ & $54.5(24.0)^{\circ} \mathrm{A}$ & $0.3(0.5)^{\circ} \mathrm{A}$ & $13.3(12.0)$ \\
\hline Decapoda & $0.8(0.5)$ & $0.5(0.6)$ & $0.8(1.0)$ & 0 & $0.7(0.6)$ \\
\hline Isopoda & $0.3(0.5)$ & 0 & $2.0(3.4)$ & $0.8(1.5)$ & $2.7(4.6)$ \\
\hline Tanaidacea & $33.0(15.8)^{\circ}$ & $2.3(1.5)$ & $4.0\{6.1\}$ & $0.8(1.0)$ & $1.3(1.5)$ \\
\hline Pelecypoda & $0.5(0.6)$ & $0.8\{1.0\}$ & $0.5(0.6)$ & $1.0(0.8)$ & $1.0(1.7)$ \\
\hline Gastropoda & $7.9(11.5)^{\circ}$ & $0.5(0.6)$ & $11.8(6.8)^{\circ}$ & $34.0(174)^{\circ}$ & $10.0(6.1)$ \\
\hline Nemertinea & $4.0(2.2)$ & $2.5(2.1)$ & $2.5(2.5)$ & $1.0(1.4)$ & $4.3(3.1)$ \\
\hline Sipuncula & $3.0(3.5)$ & $1.0(1.2)$ & 0 & $0.5(1.0)$ & 0 \\
\hline Total 'mobile fauna' & - & - & $16.5(7.7)$ & $23.0(9.5)$ & $30.3(11.6)$ \\
\hline 'Mobile fish' & - & - & $0.8(1.0)$ & $0.5(0.6)^{\circ} \mathrm{A}$ & $6.7(6.4)$ \\
\hline 'Mobile decapods' & - & - & $15.8(6.9)$ & $22.5(9.3)$ & $23.7(5.5)$ \\
\hline 'Mobile' Palaemonetes & - & - & $13.0(7.2)$ & $21.0(8.8)$ & $18.0(5.3)$ \\
\hline 'Mobile' Penaeus & - & - & $2.0(1.4)$ & $1.5(1.7)$ & $3.0(2.0)$ \\
\hline
\end{tabular}


amphipods inside the cages (control < control cages $<$ inclusion cages, $\mathrm{p}<0.05$ ).

However, the control samples showed significantly greater abundances of gastropods than either the control cages or inclusion cages. No other comparisons from the core samples showed significant differences. Among comparisons of treatments based on the mobile fauna samples, a significantly greater number of fish were found in the control cages than in either the controls or inclusion cages.

\section{DISCUSSION}

All four experiments with the shrimps Penaeus duorarum and Palaemonetes intermedius indicated that both species may exert strongly negative effects on the density of macrobenthos associated with seagrasses in the Indian River. Particularly affected by $P$. duorarum were all the small crustacean groups, as might be expected given the generally epifaunal habits of these groups. Surprisingly, in both experiments it was found that the polychaetes, which have a large infaunal component, were also sharply decreased in abundance. Observations of $P$. duorarum in the tank experiment indicate that they spend a great deal of time burrowed into the sediment and that the rhizome mat of Halodule wrightii is of little impedance to this activity. Whether the mortality of the polychaetes results from direct consumption by $P$. duorarum during these burrowing activities or results from sediment disturbance or both these factors is not certain

Palaemonetes intermedius also caused significant decreases in most of the smaller crustacean groups except the isopods. $P$. intermedius was a much less effective predator on polychaetes than was Penaeus duorarum, possibly due to the fact that $P$. intermedius does not burrow in the sediment to the extent that $P$. duorarum does. The observed impact of $P$. intermedius on density of gastropods was primarily due to decreases in the small, relatively thin-shelled species Bittium varium. Perhaps more remarkable is that both species of shrimps were able to remove almost completely the sipunculid Phascolion cryptus which primarily inhabits gastropod shells. The role of shrimps in the population biology of these two species may need closer attention.

The potential predatory impact of the epibenthic shrimps on benthic communities has been little noted. Welsh (1975) indicated that the major role of Palaemonetes pugio in a salt marsh ecosystem may be as a detritivore. Odum and Heald (1972) suggested that Penaeus duorarum and Palaemonetes intermedius are at most opportunistic omnivores on the basis of gut content analyses. Young et al. (1976) attributed significant predatory effects by decapod crustaceans of Indian River seagrass beds largely to the xanthid, alpheid, and portunid families. However, Reise (1977) documented that the shrimp Crangon crangon is an effective predator on the macrofauna of muddy sediments. Nelson (1979a) showed that Palaemonetes pugio is capable of preying on amphipods, and Bell and Coull (1978) demonstrated that this species may have significant predation/disturbance effects on the meiofauna of a salt marsh. The accumulating evidence indicates that the role of several of the families of shrimp in structuring macrobenthic communities may be much greater than formerly thought.

Predation by the pinfish Lagodon rhomboides had a much smaller effect on the seagrass macrobenthos than might have been anticipated, in that no significant food preferences for any group of species (from the cores) was found in either laboratory or field experiments. Young and Young (1978) reported a similar lack of effects due to pinfish feeding. These results can be explained largely by the fact that pinfish undergo considerable alterations in food utilization over the growth period from juvenile to adult (Carr and Adams, 1973; Adams, 1976; Stoner, 1980). Fish of the size used in the present experiments and by Young and Young (1978) were shown by Carr and Adams (1973) to feed primarily on fishes and shrimps. The larger fishes and shrimps were indeed the only groups apparently preferentially consumed in the field enclosures relative to the control cages. Experimental predation intensity may also be important, and although higher than that reported by Young and Young (1978), may still have been too low for the short duration of the experiment. In spite of these results it should be recognized that considerable evidence indicates that smaller pinfish can be extremely important predators in seagrass ecosystems (Carr and Adams, 1973; Adams, 1978; Nelson, 1797a, 1979b; Stoner, 1979, 1980). The control cages in this experiment appear to have acted to exclude effectively such smaller size classes of $L$. rhomboides, resulting in the observed increases in smaller decapods, primarily Hippolyte pleurocantha and Pagurus c.f. bonairensis, and the isopods Cymodoce faxoni and Erichsonella attenuata. This is further evidence that predation in general has a significant impact on species densities of some organisms in Indian River seagrass beds.

The experiments with the blue crab Callinectes sapidus were equivocal at best, with a significant decrease of total macrobenthos occurring in the laboratory experiment and a significant increase occurring in the crab inclusion cages in the field experiment. In fact, amphipod abundances in the field experiments, primarily due to Cymadusa compta, were 
greater than controls and greater in the crab inclusion cages than in the control cages. One possibility is that the crabs effectively reduced the density of other amphipod predators inside their cages, allowing a greater increase than would have occurred otherwise. That this predator reduction may have occurred is indicated by the greater abundance of fish in the control cages as compared with the crab cages. Such a difference in predator density may also explain the observed decrease in gastropods in the control cages. One indication of this is that the small gastropod Bittium varium, which could be easily consumed either by crabs (Orth, 1977) or fish (Adams, 1976), decreased in both cage treatments whereas the larger, stout shelled Nassarius vibex decreased only in the crab enclosures. The apparent ineffectiveness of the crabs in reducing densities of groups other than the gastropods in the field experiment may be the result of an insufficient predator density for the short experimental duration or to the large size of the C. sapidus used. Whether predation by $C$. sapidus was hindered also by the presence of the relatively more intact rhizome mat in the field as compared with the tank experiment is not known. It is also possible that larval recruitment, which could occur in the field but not in the tank experiment, may have generated some of the differences observed in the 2 sets of experiments.

Comparisons among the field experiments indicate interesting relationships between certain taxa and predation. In all cases, the amphipods showed increases inside control cages as compared with the uncaged controls. These results support other evidence (Young and Young, 1978; Nelson et al., in press) that the amphipods of the Indian River seagrass habitats are strongly subject to predation. Other groups show little consistent relationship to the presence of cages acting to exclude predators, confirming the conclusion of Young et al. (1976) and Young and Young (1978) that great variability and unpredictability exists in the response of a given species of seagrass macrobenthos to caging. One factor which may explain some of this variability is the relationship of polychaete and decapod abundances (Nelson, in press). Polychaete abundance shows a significant negative exponential relationship with decapod density which rapidly levels off beyond a density of approximately 20 decapods per $0.25 \mathrm{~m}^{2}$ and is little affected by even sizable increases in decapod abundance beyond this point. This relationship appears independent of the presence of a cage or of season. An important implication for predator exclusion experiments in this seagrass habitat is that if a cage structure contains more than a density of approximately 80 per $\mathrm{m}^{2}$ of even such small decapods as Palaemonetes intermedius, no reduction of predation pressure on the polychaetes may result from the supposed 'predator exclusion' structure. An additional factor causing variability may be the recruitment of decapod crustaceans into cage structures ( R. W. Virnstein, pers. comm.). Even with the small mesh size and short term nature of the present experiments, some evidence of decapod recruitment into cages occurred. Such problems may have contributed to the unpredictable and often non-significant responses of polychaetes to predator exclusion observed by Young and Young (1978) and Virnstein (1978).

Having demonstrated the decapod crustaceans to be potentially important predators regulating densities of seagrass macrobenthos, it is necessary to consider their actual significance. Because of their short duration, the experiments utilized predator densities higher than estimated mean abundances in the seagrass beds (Gore et al., 1981). However, the densities used may not be totally unrealistic. Given the extreme difficulties in effectively sampling decapod crustaceans in seagrass (Virnstein, pers. comm.), densities may be higher than estimated by the seining techniques used by Gore et al. (1981). The density of Palaemonetes intermedius in one control cage was of the same order as in the experiments. Decapod species may be sufficiently dense in local patches to regulate densities of seagrass associated macrobenthos. Aggregations of decapods such as those observed also may produce significant spatial patchiness in the macrobenthic assemblage.

The evidence gathered from the present experiments indicates that the primary food webs in seagrass ecosystems may be far more complex than previously indicated (Kikuchi, 1966; Littlejohn et al., 1974). The presence of a diverse and abundant class of opportunistic omnivores in addition to the numerous carnivorous fishes may yield a predator regulated community (at the lower trophic levels; Menge and Sutherland, 1976) fundamentally different in its structure and stability than other systems, e.g. some rocky intertidal communities. This possible difference is due to the fact that a single keystone species per se may be lacking in seagrass systems, at least in respect to the overall macrobenthic food web. The significance of the keystone species concept is also considerably obscured in seagrass systems by ontogenetic changes in diet of some important species, e.g. Lagodon rhomboides (Stoner, 1980), so that a given species' role may greatly change throughout the course of a year. Whether the decapod crustaceans as a group serve the equivalent function of the keystone species is unclear.

Acknowledgements. This study was carried out while the author was a Harbor Branch Institution Postdoctoral Fellow The manuscript was written during the author s tenure as a Royal Norwegian Council for Scientific and Industrial 
Research Postdoctoral Fellow. The assistance of both organizations is gratefully acknowledged.

Invaluable assistance with the field work and with species identifications were generously provided by $M$. A. Capone, P. S. Mikkelson, P. M. Mikkelson, D. H. Mook, P. H. Hastings, L. E. Poult, K. A. Wilson, and R. H. Gore Special thanks are due K. D. Carms, R. W Virnstein, and M. A. Nelson for their constant assistance in all respects of the research

\section{LITERATURE CITED}

Adams, S. M. (1976). Feeding ecology of eelgrass fish communities. Trans. Am. Fish. Soc. 105: 514-519

Bell, S. S., Coull, B. C. (1978). Field evidence that shrimp predation regulates meiofauna. Oecologia (Berl.) 35: $141-148$

Carr, W. E. S., Adams, C. A. (1973). Food habits of juvenile marine fishes occupying seagrass beds in the estuarine zone near Crystal River, Florida. Trans. Am. Fish. Soc. 102: 511-540

Gore, R. H., Scotto, L. E. Wilson, K. A., Gallaher, E. E. (1981). Studies on decapod crustaceans from the Indian River region of Florida. XI. Community composition, structure. biomass and species-areal relationships of seagrass and drift-algae associated macrocrustaceans. Estuar coast. Shelf Sci. 12: 485-508

Grubbs, F. E. (1969). Procedures for detecting outlying observations in samples. Technometrics 11: 1-21

Kikuchi, T. (1966). An ecological study on animal communities of the Zostera marina belt in Tomioka Bay, Amakusa, Kyushu. Publ. Amakusa Mar. Biol Lab. 1. 1-106

Littlejohn, M. J., Watson, G. F., Robertson, A. I. (1974). The ecological role of macrofauna in eelgrass communities. In: Shapiro, M. A. (ed.) A preliminary report on the Westernport Bay environmental study. Ministry for Conservation, Victoria, pp. 395-406

Menge, B. A., Sutherland, J. P. (1976). Species diversity gradients: synthesis of the roles of predation, competition, and temporal heterogeneity. Am. Nat. 110: 351-369

Nelson, W G. (1979a). Experimental studies of selective predation on amphipods: consequences for amphipod distribution and abundance. J. exp. mar. Biol. Ecol. 38: 225-245

Nelson, W G. (1979b). An analysis of structural pattern in an eelgrass (Zostera marina) amphipod community. J. exp. mar. Biol. Ecol. 39: 231-264

Nelson, W. G. (in press). The role of predation by decapod crustaceans in seagrass ecosystems. 15th European
Marine Biology Symposium, Kiel, 1980. Kieler Meeresforsch

Nelson. W G., Carrns, K. D. Virnstein, R. W (in press). Seasonality and spatial patterns of seagrass associated amphipods of the Indian River Lagoon, Florida. Bull. mar Sci.

Odum, W E., Heald, E. J. (1972). Trophic analyses of an estuarine mangrove community. Bull. mar. Sci. 22 : $671-738$

Orth, R. J. (1977). The importance of sediment stability in seagrass communities. In: Coull, B. C. (ed.) Ecology of marine benthos. Columbia: University of South Carolina Press, Columbia, pp. 281-300

Reise, K. (1977). Predator exclusion experiments in an intertidal mud flat. Helgoländer wiss. Meeresunters. 30: 263-271

Sokal, R. R., Rohlf, F. J. (1969). Biometry, W. H. Freeman and Co., San Francisco

Stoner, A. W. (1979). Species specific predation on amphipod crustacea by the pinfish Lagodon rhomboides: Mediation by macrophyte standing crop. Mar. Biol 55: 201-208

Stoner, A. W. (1980). Feeding ecology of Lagodon rhomboides (Pisces: Sparadae): Variation and functional responses. Fish. Bull. U.S. 78: 337-352

Thayer, G. W., Adams, S. M., LaCroix, M. W. (1975). Structural and functional aspects of a recently established Zostera marina community. In: Cronin, E. L. (ed.) Estuarine research. Academic Press, New York, pp. 518-540

Virnstein, R. W. (1977). The importance of predation by epibenthic crabs and fishes on benthic infauna in Chesapeake Bay. Ecology 58: 1199-1217

Virnstein, R. W. (1978). Predator caging experiments in soft sediment: Caution advised. In: Wiley, M. L. (ed.) Estuarine interactions. Academic Press, New York, pp. 261-273

WeIsh, B. L. (1975). The role of the grass shrimp Palaemonetes pugio in a tidal marsh ecosystem. Ecology 56: 515-530

Young, D. K. (1978). Regulation of species densities of seagrass-associated macrobenthos: evidence from field experiments in the Indian River estuary, Florida. J. mar. Res. 36: 569-593

Young, D. K., Buzas, M. A., Young, M. W. (1976). Species densities of macrobenthos associated with seagrass: A field experimental study of predation. J. mar Res. 34: $577-592$

Young, D. K., Young, M. W (1977). Community structure of the macrobenthos associated with seagrass of the Indian River estuary, Florida. In: Coull, B. C. (ed.) Ecology of marine benthos. University of South Carolina Press, Columbia, pp. 359-382 